Intersections

Canadian Journal of Music

Revue canadienne de musique
Intersections CANADIAN JOURAL OF MUSIC

\title{
Survey of University-Based Music Programs in Canada
}

\section{Don McLean et Dean Jobin-Bevans}

Volume 29, numéro 1, 2009

URI : https://id.erudit.org/iderudit/039112ar

DOI : https://doi.org/10.7202/039112ar

Aller au sommaire du numéro

\section{Éditeur(s)}

Canadian University Music Society / Société de musique des universités canadiennes

ISSN

1911-0146 (imprimé)

1918-512X (numérique)

Découvrir la revue

Citer cette note

McLean, D. \& Jobin-Bevans, D. (2009). Survey of University-Based Music

Programs in Canada. Intersections, 29(1), 86-104.

https://doi.org/10.7202/039112ar

\section{Résumé de l'article}

Cet article fournit une vue d'ensemble des programmes musicaux universitaires au Canada. Il s'appuie sur des informations récoltées au cours des études réalisées par des membres de la Société de musique des Universités Canadiennes (SMUC) — universités, collèges et conservatoires. Ces études ont été effectuées entre 2005 et 2009. Le présent rapport se concentre sur les statistiques concernant les inscriptions des étudiants et le personnel enseignant, et procure des données fondamentales sur différents programmes de premier et deuxième cycles. C'est un premier pas dans le partage de l'information qui pourra faciliter un plaidoyer avisé afin de promouvoir l'éducation musicale au niveau des études supérieures à la fois au sein et au-delà des institutions.
Tous droits réservés (C) Canadian University Music Society / Société de musique des universités canadiennes, 2009
Ce document est protégé par la loi sur le droit d'auteur. L'utilisation des services d'Érudit (y compris la reproduction) est assujettie à sa politique d'utilisation que vous pouvez consulter en ligne.

https://apropos.erudit.org/fr/usagers/politique-dutilisation/ 


\title{
SURVEY OF UNIVERSITY-BASED MUSIC PROGRAMS IN CANADA
}

\author{
Don McLean and Dean Jobin-Bevans
}

\section{Purpose}

The purpose of this study is to provide a compact overview of music programs being offered at Canadian institutions of higher education. Our goal is to make information available to the broader community-information that is often surprisingly hard to come by-so that the shared results can help make connections between schools of similar and different sizes, provide a better picture of programs offered and teaching resources available, and facilitate informed advocacy in support of music in higher education.

\section{MeTHODOLOGY}

Surveys were distributed following the 2005 meeting of the Canadian University Music Schools (CUMS) to all institutional members (universities) and associate members (colleges and conservatories), with three additional survey waves as follow-up to the meetings in 2006, 2007, and 2008. A preliminary version of our findings was presented to the Standing Committee of Institutional Members of CUMS at the 2008 annual meeting. Surveys were administered in paper format, accompanied by a letter of introduction and a sample copy of a completed survey by the Schulich School of Music of McGill University.

The idea for the survey came from Don McLean when, as chair of the Standing Committee of Institutional Members of CUMS, he found himself frustrated with the lack of information available on member institutional profiles. At the time, Dean Jobin-Bevans was director of the McGill Conservatory of Music, the community program of the Schulich School of Music of McGill University, and found himself unable to find information on community schools and institutions for pre-university training of musicians, whether associated with CUMS member institutions or as independent conservatory structures (such as the Royal Conservatory of Music, le Conservatoire de musique et d'art dramatique du Québec, Conservatory Canada, the Mount Royal Conservatory, the Victoria Conservatory of Music, the Vancouver Academy of Music, etc.).

Despite our repeated efforts to solicit information from all institutions across the country, the response rate is far from complete. We received responses from twenty-nine university-based music programs. Twelve institutions did not report back over the four waves of the survey, and several larger schools remain notably absent. Of course, in the time between the first (2005) and final (2009) waves of the survey, several schools have improved the information available on their websites. Yet the kind of enrolment information 
(by specialization) that we requested in the survey is seldom available on such sites. And it was important to get the information directly from the institutions wherever possible.

While we hope that a more comprehensive overview of music training in Canada can be achieved, this article has the more modest goal of sharing at least some of the information we have been able to gather to date. It is important to remind readers that the data were harvested in four waves, so that discrepancies between the information as gathered and an institution's current numbers are unavoidable. (This is true even for the authors' own institutions.) We are aware that the lack of detail may be disappointing. However, it is the objective of this study to present the broader picture, to show the initial value of such a survey, and to encourage further collaborative work.

There will be several opportunities for further research, whether from updates to the data we have already collected or from alternative surveys, and it is hoped that more detailed and focused studies will emerge.

\section{QUestionnaire STRUCTURE}

The survey was divided into five sections of data capture: (1) general contact and institutional information (including information on conservatory community programs where applicable), (2) programs offered at undergraduate, graduate (including doctoral), and diploma levels, (3) breakdown of staffing categories (tenure-track, non-tenure-track, support), (4) administrative/organizational structure, and (5) facilities (principally concert and recital performance spaces). In addition, institutions were invited to append a brief description of their programs and to answer the informal question, "What is your institution known for?" The survey document (Canadian University Music Society Institutional Questionnaire [version] 2008) is reproduced as Appendix A.

\section{REPORT}

Following the format we used in our preliminary presentation to the Standing Committee of Institutional Members in 2008, this report focuses on student enrolment and staffing. The rationale for selecting these two parameters from the mass of information collected was that students and staffing are obviously key elements in the description of institution-based programs. Moreover, as we show, the data gathered in these areas sort broadly by institutional size and suggest fruitful ways for immediate and future cross-institutional comparison. The report then goes on to provide basic data on graduate and undergraduate programs, with information on several specializations. We continue with some general observations on the rapidly changing landscape of colleges and conservatories, and conclude with some recommendations for further collaboration and research.

\section{ENROLMENT}

Data capture for this metric was divided into three segments of institutional program offerings - undergraduate, graduate, and diploma programs-in an 
attempt both to quantify the number of schools offering programs at each of these levels, and to better understand the correlation between student population and degree offerings. The survey was designed to ascertain not only the total enrolment for each institution in these student streams but also, where applicable, the number of students per specialization (e.g., composition, performance, jazz, etc.). We will deal with the overall numbers first.

The following observations emerged from the data collected for total student enrolment per institution. There are three broad groups of schools: larger schools with music student populations of 300 or more, medium schools with 100 to 299 students, and smaller schools with populations of fewer than 100 . This information is summarized in Appendix B. Seven schools were represented in the larger group, characterized by the presence of both graduate (including doctoral) and undergraduate programs in a variety of areas of specialization. Ten schools were represented in the medium group, characterized primarily by their offering of undergraduate music programs but also providing niches of graduate specialization in about half the cases. Thirteen schools were represented in the smaller group, which had undergraduate music programs (usually leading to the B.Mus. degree) that remain structurally distinct from arts programs with music concentrations (B.A. in Music). Though numbers are provided for the diploma programs offered by several larger and medium-sized schools, the variability of the level and intent of these programs made the data difficult to codify within the limits of the present study; a more targeted analysis of diploma programs would be required.

\section{STAFFING}

Data capture for this metric included five categories: full-time tenure-track (FTTT), part-time tenure-track (PTTT), full-time non-tenure track (FTNT), part-time non-tenure track (PTNT), and hourly-rate instructors. This information is summarized in Appendix C. It is evident that these staffing categories are far from rigid and are often variably expressed within, let alone between, institutions. The common understanding of FTTT seems clear enough, but the apparent paucity of PTTT numbers makes the need for this as a separate category doubtful, a situation that will perhaps change, however, as cohorts of senior colleagues begin to seek phased retirement. On the other hand, it appears that having some full-time teaching staff in the non-tenure stream (FTNT) is important to the operation of several institutions, thought the exact role and career path of these individuals could not be determined from the data. It is an open question whether this represents an employment category in transition or a tactical move to risk-manage full-time positions outside the constraints of tenure and promotion, and the budgetary and political vulnerabilities of tenure-track allocations.

The distinction between PTNT and hourly-rate staff can also be obscure. For example, Wilfrid Laurier University reports significant numbers in both categories, whereas the University of Toronto reports only PTNT staff. At McGill, the PTNT group includes longer-serving professional musicians (notably 
Montreal Symphony Orchestra principals) who hold appointments that feature access to the university benefits program that go beyond those available to hourly-rate/sessional staff. Overall, despite this blurring of the categories, it is our sense that the numbers concerning tenure-track and/or otherwise fulltime teaching employees versus contractual part-time and/or hourly-rate instructors are valuably shared.

It is important to remind ourselves - and perhaps more important to keep senior university administrators informed - of the key yet variable roles played by both types of staff. It is difficult to run an institution without a critical mass of full-time tenured or tenure-track staff: commitment to the development of programs, the execution of service functions, and the definition of the character of the school depend on their presence. At the same time, the role of part-time staff who usually function in other facets of their lives as musical professionals (performers, composers, specialist coaches, teachers, etc.) is crucial to the pursuit of the highest local or (inter)national aspirations for artistic and pedagogical achievement, and for integration into the local artistic community. The balance between them (full-time and part-time staff) is driven all too often by economic constraints, whereas its consideration should be an ongoing part of a school's strategic direction.

One significant convergence point of enrolment and staffing data is the ratio of total student numbers to FTTT. For most general arts and science programs the ratio of students to faculty is typically anywhere from the mid-teens (fifteen to one) to the mid-twenties (twenty-five to one). But the nature of high-level musical training, with its central positioning of one-on-one studio teaching and small-group craft building necessitates lower student-to-staff ratios. Leading music institutions (in the United States and the European Union) can have ratios of ten to one or lower. For the CUMS institutions surveyed, studentsto-FTTT information is summarized in Appendix D. It will be seen that the ratios vary widely. Even among the larger programs the range varies from ten to one (University of Toronto) to twenty to one (Laval). Among the medium programs, Brandon and Memorial are in the admirable nine to one zone. Queen's eighteen to one ratio perhaps needs to take into account its previously reported larger number of PTNT staff. And Sherbrooke's anomalous thirtyfive to one ratio reflects a transitional moment in its staffing, partially rectified since the time of the survey. Among the smaller programs, lower ratios are not uncommon, since anywhere from three to ten FTTT with a total undergraduate population of thirty-five to eighty-eight students will produce such results. Within this group, the University of Toronto at Scarborough's twenty-three to one ratio probably reflects the nature of its program in comparison with that of its downtown Faculty of Music counterpart, but the higher ratios for Lakehead, Bishop's, and Laurentian, for example, indicate the challenges of having an FTTT denominator stuck in the low single digits.

The real strategic question for all institutions is to determine where their teaching and research strengths lie and drive towards them. The burden of comprehensiveness is a refrain that is becoming increasingly difficult to sustain, one that is beginning to appear an unaffordable luxury to continue to 
envisage and be able to deliver, even for the larger organizations. Individual institutions and governmental jurisdictions must face strategic decisions about what specializations they will offer in graduate and undergraduate programs. These decisions of course are likely to be based, at least in part, on what programs are being offered where-to which topic our survey now turns.

\section{Program Offerings}

\section{Undergraduate Programs}

Selected information on undergraduate programs is provided in Appendix E. It is a feature of many music programs that the designation "general" is more easily defined by what it isn't rather than what it is. General Music implies the "non-designation" of a specialization stream. The purpose may be to allow maximum flexibility in the choice of course of study, or because numbers and resources do not warrant the creation of specialized areas. In a number of smaller institutions the General Music stream is the only one available. Some of these also use the Bachelor of Arts with Major in Music as the only degree designation (Bishop's, Guelph, Laurentian, Waterloo). But many institutions feature both Bachelor of Music and Bachelor of Arts in Music paths, the former distinguished mostly by emphasis on practical instruction and ensemble performance within rather than outside of the fee structure of the degree program. The General Music designation is also sometimes to be understood as "non-Performance." All of the larger, most of the medium, and (somewhat to our surprise) several of the smaller schools have Performance specialization streams. These are, one would expect, dependent on available staffing expertise. Our survey requested a breakdown (where possible) of Performance offerings under the headings of keyboard, voice, orchestral instruments, early music, and jazz; and a breakdown of non-Performance offerings under the headings composition, music education, history, music technology, and theory. Though all of this information strikes us as useful at the detail level, we felt that providing the data for a few streams was most valuable at this time. Appendix E captures the numbers for General Music (B.Mus.) and/or Arts (B.A.) designations, Bachelor of Music Education streams (many constructed as concurrent B.Mus./B.Ed. degree and provincially based teacher certification programs), as well as Performance and Composition specializations for the responding institutions. It also provides an "Other" column where interdisciplinary programs in music technology, sound recording, and multimedia studies, as well as music therapy, are expressed.

\section{Master's Programs}

As summarized in Appendix F, there are fourteen master's programs among the respondent schools. Across Canada, there are thus approximately seven hundred students at the master's level in music. The majority of students (51 per cent) are in Performance-based M.Mus. programs. The non-Performance M.Mus. streams (19 per cent) are, for the most part, in composition and music education (sometimes more narrowly, music pedagogy). The exceptions are the 
M.Mus. in Sound Recording at McGill (approximately twelve students) and the M.M.T. (Master's in Music Therapy, approximately twelve students) at Wilfrid Laurier. The M.A. is offered in six schools in the traditional academic research disciplines of musicology, ethnomusicology, and music theory. Of the fourteen responding schools offering master's degrees, nine go on to offer doctoral degrees.

\section{Doctoral Programs}

Of the institutions responding to the survey, nine offer programs leading to the doctoral degree. Six of these are in the larger group and three in the medium group. Two types of doctoral degrees are awarded: the Doctor of Music (D.Mus., or Doctor of Musical Arts, D.M.A.) and the Doctor of Philosophy (Ph.D.). Appendix $G$ provides a summary of the total numbers of undergraduate, graduate, and doctoral students in the two streams. The D.Mus. (or D.M.A.) in Performance is offered at four institutions, and the D.Mus. in Composition at five institutions, among those reporting during the survey. The total number of doctoral students in Performance across Canada is just under one hundred, and in Composition around sixty. The Ph.D. in Music is offered in the fields of musicology, ethnomusicology, music education, music theory, music technology, and sound recording. Musicology is often the general descriptor, though several institutions have further specialized streams; e.g., ethnomusicology at Memorial University of Newfoundland and the University of British Columbia, and music theory at McGill University, the University of British Columbia, and the University of Toronto. The Ph.D. in music education is offered at four institutions: Calgary, McGill, Toronto, and Laval (with its didactique instrumentale program at both master's and doctoral levels). The music technology and sound-recording doctoral programs are unique to McGill. Broadly speaking, national enrolments at the doctoral level in musicology and ethnomusicology number approximately one hundred students, in music education around twenty-five, in music theory (where not subsumed within musicology) about ten, and in music technology and sound recording around twenty. Awareness of these totals-the overall scarcity of doctoral students in music and their even smaller cohorts by specialization-reinforces the desirability to create opportunities for collaborative engagement between institutions and across jurisdictions.

\section{FaCilities AND Events}

Respondents were asked to list concert/performing venues, including seating capacity, and to approximate the number of events that take place in an average academic year. Appendix H provides an overview of the theatres, concert halls, and recital halls, or general-purpose auditoria available within the institutions surveyed and the approximate number of music events undertaken annually. In some cases we were informed that a given space used for musical events was public or under the control of the university rather than the music unit, the implication being that its availability for music performance and related 
rehearsal/teaching functions was curtailed. It came as no surprise to the researchers that there was a direct correlation between the number of concert events offered and the availability to the music unit of performance facilities. The larger the institution's performance program offering, the greater the need for access to concert facilities both inside and outside the university, including concert halls, churches, and community theatres. In general, schools that offer smaller performance-based programs were more likely to accommodate their events in concert and recital facilities "in-house" or on campus. It should be emphasized that this survey makes no assessment of the quality of the facilities or of their appropriateness to the events they are expected to house. We anticipate, however, that a closer examination of facilities across the country would confirm that the development of high-quality performance, rehearsal (as well as teaching), and practice spaces remains the final frontier for many institutions.

\section{Colleges And Conservatories}

The initial wave of this survey included an effort to capture data from colleges and conservatories. Notwithstanding the unique challenges and conditions shared by university-based schools of music (full members of CUMS), particularly those of comparable size, it is our opinion that an overview of post-secondary musical training and education in Canada must extend to the programs offered by our colleges and conservatories (some associate members of CUMS). Our intention was to include them in the survey with the goal to develop a better understanding of the complexities involved. Challenges of data gathering and shifting regimes did not allow the comprehensive overview that we are convinced is needed.

This situation has become further complicated by the emergence of degree programs at the college level in some provinces, such as British Columbia's Kwantlen College and Vancouver Community College, Alberta's Mount Royal College Conservatory and Grant McEwan College, and Ontario's Humber College. (This list is far from complete and is not unique to music programs.) Thus, institutions that formerly offered junior college programs that led to transfer to upper-level university undergraduate degree programs were (rather suddenly, from the perspective of many) given clearance to offer full degree programs. In Quebec, the CEGEP system (Collège d'enseignement général et professionnel) offers (post-) secondary music programs through French- and English-language institutions that transfer (not always smoothly) to university programs at the equivalent of the second year of an undergraduate degree.

On the conservatory side, the Royal Conservatory of Music of Toronto and the Vancouver Academy of Music have developed a degree-granting link with Thompson Rivers University in British Columbia (formerly designated B.C. Open University), reinforcing a broader international trend to provide degree (rather than "just" diploma) status to graduates of conservatory-model professional training programs. This has resulted in predictable turf wars (particularly within geographic zones where both types of institutions coexist), such 
that the distinction between traditional conservatory diploma programs and university degree programs in music begins to erode, and perceived paths of artistic and academic quality collide. A parallel situation has just developed in Quebec with the reincorporation of the Conservatoire system as a degreegranting institution, though its diplomas have long been recognized as transferable equivalents (within music performance and composition) by university sister institutions in Quebec and (to a variable extent) internationally. In compiling our survey, we received helpful responses from four colleges and three conservatories. However, the distinct nature of these organizations, the incompleteness of the data received, as well as the changing relations between colleges and universities partially described above, made it evident that a separate study would be required to do justice to this complex and rapidly evolving landscape. Therefore, apart from the preliminary observations given here, the current report focuses only on selected data from university-based institutions.

College programs aside, conservatories (or similarly named institutions) come in at least two types: independent organizations, not affiliated with universities or colleges, and community or preparatory schools embedded within CUMS member institutions. (We say "at least two types" because numerous community-focused networks of teachers and programs developed through organizations such as Conservatory Canada or the Royal Conservatory of Music [RCM], or the successful pre-professional training programs associated with some otherwise largely community-centred teaching institutions such as the Mount Royal College Conservatory or the Victoria Conservatory of Music reveal the realities of a far more complex spectrum.) Among the independent organizations we include the Royal Conservatory of Music of Toronto (with its distinctive national reach), and Le Conservatoire de musique et d'art dramatique du Québec (with its multiple regional branches). Both institutions have professional level training programs (the Glenn Gould School at the RCM, the diplomes et concours of the Conservatoire), but both also seek to develop young talent, the RCM more on the British-American model of community outreach, the Conservatoire more on the French-Soviet model of identifying young talent and fostering it through a continuous pedagogical regime. Among the embedded schools affiliated with CUMS member institutions, we were given information on ten: Lethbridge, Regina, Brandon, Manitoba, Canadian Mennonite, McGill, Montréal, Sherbrooke, Laval, and New Brunswick, though we know that others exist. The whole question of the role of such programs-their balance between community service and outreach versus preparation and recruitment for the host institution-warrants focused research and thorough review that is beyond the scope of the present study.

As an informal indicator of perceived integration and valuation, universities reporting conservatory or community music school programs were asked to rate on a seven-point scale their institution's level of support for that entity. Of those that responded, the general attitude is supportive (with an average score of two out of seven on the side of "strongly supportive"). Many universities enthusiastically affirm their community school and recognize the impact that it has on visibility and outreach. Anecdotally, colleagues report that community 
school music programs are beginning to be integrated into the overall strategic recruitment plans of their universities, and that graduates of the community school often continue their post-secondary music studies at the affiliated university. From a financial perspective, most community school programs function as self-funded entities that roll up to budget lines within the affiliated music academic unit (department, school, faculty) of the host university, sometimes with attendant expectations that they meet a revenue target towards the bottom line or at least break even. From the institutional perspective, these programs are recognized for the public visibility and outreach value that they bring to the host institution and to the communities that they serve.

\section{Concluding Comments}

This report is the result of a survey, itself a first attempt at collecting and sharing basic information on university-based music programs in Canada. Basic as it is, that information proved not easy to come by, and it will remain somewhat frustrating (for the authors, as for the readers) to know that the data presented here are both inevitably inaccurate at the detail level (because of the timeframe of collection and the imprecision of certain categories) and annoyingly incomplete (as a result of the unresponsiveness of a number of institutions and the rapid rate of change in the recent higher-educational landscape). Nevertheless, we hope that the preliminary observations we have made and the data we have put forward constitute a few steps in the right collaborative direction.

When this project was first launched in 2005, the CUMS Conference welcomed composer Prof. Johannes Johansson (principal of the Royal College of Music in Stockholm, formerly director of the Malmö Academy of Music), president of the Association of European Conservatories (AEC), who presented basic information on the AEC and its efforts to develop international and interinstitutional links within the European Union. If the EU-with its history of political animosity, linguistic multiplicity, organizational variability, and structural complexity-can produce collaboration, exchange, and commonality of purpose among its higher-educational institutions for musical training, one might think Canada would find the challenges of inter-institutional and inter-jurisdictional collaboration comparatively easy to overcome.

The authors of this study would like to envision a new wave of information gathering and sharing on the horizon. We would like to see a further exchange of data among institutional members of CUMS (expanded where appropriate to include the growing number of associate members whose changing degreegranting status now antiquates the "associate" descriptor). In our view, this data exchange should become a permanent, updatable feature of the CUMS website, with embedded links to institutional home pages and program descriptions. Once available, the information could become a catalyst for the exchange of ideas and resources between students and staff members from similar and complementary programs and institutions. And collectively, the material we together generate and develop-from the extension of the current 
survey or from alternative versions-will facilitate informed advocacy in support of higher education in music across Canada.

\begin{abstract}
This study provides a compact overview of university-based music programs in Canada based on information gleaned from surveys of institutional members of the Canadian University Music Society (CUMS) - universities, colleges, and conservatories. The surveys took place between 2005 and 2009. The current report focuses on the metrics of enrolment and staffing, and goes on to provide basic data on graduate and undergraduate programs. It is a first step in sharing information that can facilitate informed advocacy in support of music in higher education both within and beyond individual institutions.
\end{abstract}

\title{
RÉSUMÉ
}

Cet article fournit une vue d'ensemble des programmes musicaux universitaires au Canada. Il s'appuie sur des informations récoltées au cours des études réalisées par des membres de la Société de musique des Universités Canadiennes (SMUC)—universités, collèges et conservatoires. Ces études ont été effectuées entre 2005 et 2009. Le présent rapport se concentre sur les statistiques concernant les inscriptions des étudiants et le personnel enseignant, et procure des données fondamentales sur différents programmes de premier et deuxième cycles. C'est un premier pas dans le partage de l'information qui pourra faciliter un plaidoyer avisé afin de promouvoir l'éducation musicale au niveau des études supérieures à la fois au sein et au-delà des institutions. 


\section{Appendix A: Canadian University Music Society (CUMS) INSTITUTIONAL QUESTIONNAIRE, 2008}

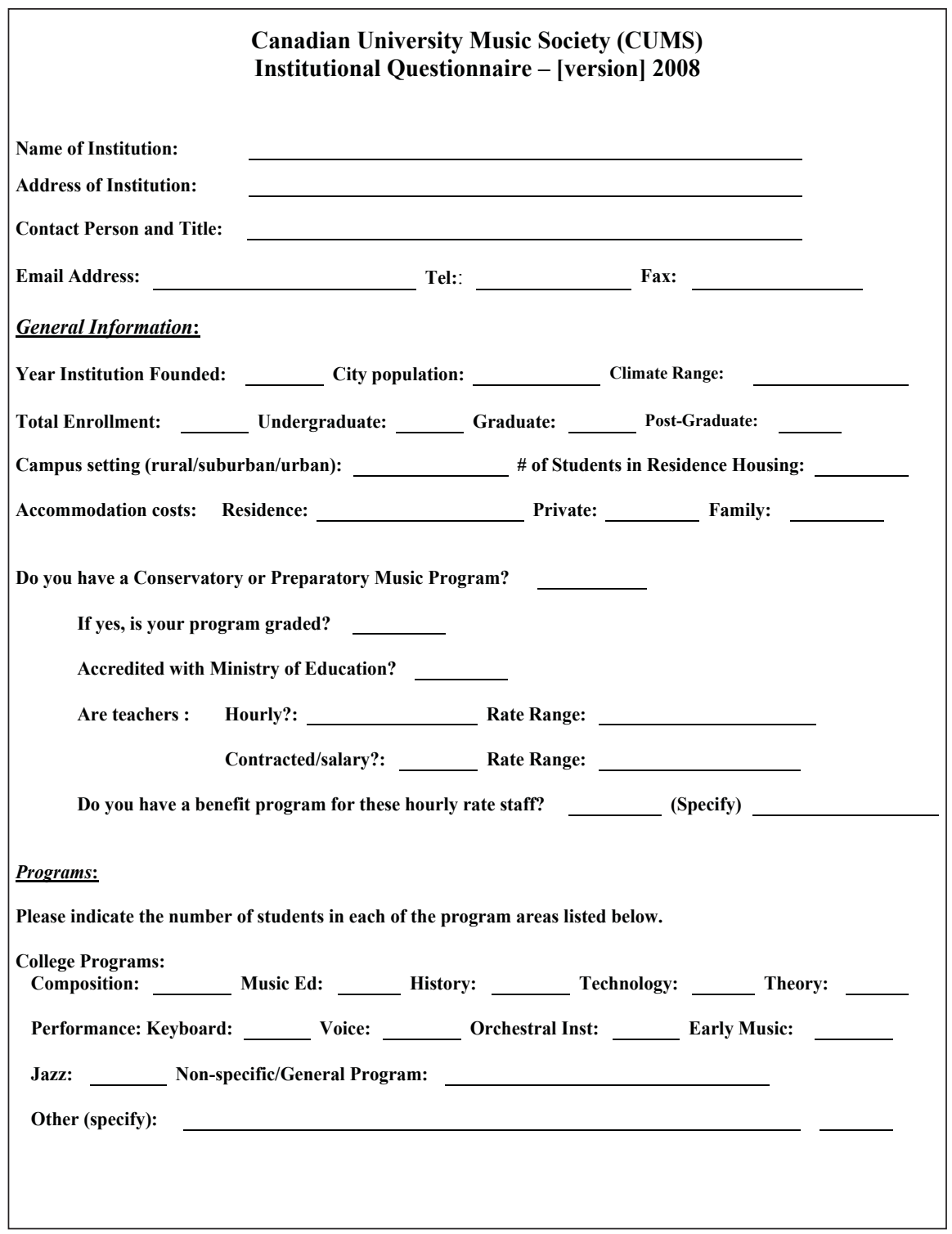


Bachelor of Music (B. Mus.):

Composition: Music Ed:

History:

Technology:

Theory:

Performance: Keyboard: Voice:

Orchestral Inst:

Early Music:

Jazz: Non-specific/General Program:

Other (specify):

Bachelor of Arts (B.A.):

Composition: Music Ed:

History:

Technology:

Theory:

Performance (specify areas):

Other (specify):

Master of Music (M.Mus.):

Composition: Music Ed:

History: Technology:

Theory:

Other (specify):

Performance: Keyboard: Voice: Orchestral Inst: Early Music:

Jazz: Conducting: Other (specify):

Master of Arts (M.A.):

Composition: Music Ed: History: Technology: Theory:

Other (specify):

Doctorate of Music (D.Mus.):

Composition: Music Ed:

History:

Technology: Theory:

Performance: Keyboard: Voice: Orchestral Inst: Early Music:

Jazz: Conducting: Other (specify):

Doctorate of Philosophy in Music (Ph.D.): Composition: Music Ed: History: Technology: Theory:

Other (specify):

Certificates \& Diplomas:

Does your institution offer a Licentiate, Artist Diploma or similar performance-focused program?

Number of students:

In what programs? (Attach description)

Does your institution offer other Fine Arts Programs? 
What is your institution known for?

\section{Staffing:}

No. of Tenure track: Full-time, non-tenure: Part-time, non-tenure:

Hourly, instructors: Rate Range:

Do you have a benefit program for hourly rate teaching staff?

Support Staff: Full-time: Sessional/Part-time:

\section{Administrative Structure:}

Areas: Departments:

School/Faculty: Division: University:

Executive Committee:

Board(s):

Facilities:

Concert Hall(s): Capacity: Recital Hall: Capacity:

Theatre: Capacity:

Total number of concerts/events per year? 


\section{APPENDIX B: TotAL STUDENT NUMBERS}

\begin{tabular}{|c|c|c|c|c|}
\hline Institution & Total & $\begin{array}{l}\text { Under- } \\
\text { graduate }\end{array}$ & Graduate & Diploma \\
\hline McGill & 818 & 508 & 274 & 36 \\
\hline UWO (Western Ontario) & 708 & 585 & 120 & 3 \\
\hline U de Montréal & 699 & 433 & 266 & - \\
\hline $\mathrm{U}$ of Toronto & 562 & 414 & 116 & 32 \\
\hline U Laval & 405 & 311 & 94 & - \\
\hline UBC (British Columbia) & 383 & 269 & 109 & 5 \\
\hline WLU (Wilfrid Laurier) & 305 & 285 & 12 & 8 \\
\hline$U$ of Manitoba & 256 & 231 & 15 & 10 \\
\hline UNB (New Brunswick) & 250 & 250 & - & - \\
\hline U of Alberta & 220 & 169 & 51 & \\
\hline U de Sherbrooke & 209 & 195 & 8 & 6 \\
\hline Memorial $U$ of Newfoundland & 200 & 165 & 35 & - \\
\hline Queen's U & 200 & 200 & - & - \\
\hline Brandon U & 172 & 160 & 12 & - \\
\hline $\mathrm{U}$ of Calgary & 153 & 125 & 28 & - \\
\hline $\mathrm{U}$ of Lethbridge & 145 & 145 & - & - \\
\hline $\mathrm{U}$ of Windsor & 113 & 113 & - & - \\
\hline Dalhousie U & 88 & 88 & - & - \\
\hline St. Fr. Xavier U & 85 & 85 & - & - \\
\hline$U$ of Regina & 76 & 70 & 6 & - \\
\hline Mount Allison U & 75 & 75 & - & - \\
\hline Canadian Mennonite U & 70 & 70 & - & - \\
\hline $\mathrm{U}$ of $\mathrm{T}$ at Scarborough & 70 & 70 & - & - \\
\hline Carleton U & 62 & 62 & - & - \\
\hline Lakehead U & 60 & 60 & - & - \\
\hline Bishop's U & 50 & 50 & - & - \\
\hline Laurentian U & 44 & 44 & - & - \\
\hline U of Guelph & 40 & 40 & - & - \\
\hline $\mathrm{U}$ of Waterloo & 40 & 40 & - & - \\
\hline Brock U & 35 & 35 & - & - \\
\hline Total & 6593 & 5347 & 1146 & 100 \\
\hline
\end{tabular}




\section{APPENDix C: STAFFing NUMBERS BY CATEgory}

\begin{tabular}{|c|c|c|c|c|c|c|}
\hline Institution & $\begin{array}{l}\text { Total } \\
\text { staff }\end{array}$ & FTTTa & PTTTb & FTNTC & PTNT ${ }^{d}$ & Hourly \\
\hline McGill & 818 & 57 & - & 1 & 27 & 90 \\
\hline UWO (Western Ontario) & 708 & 35 & - & 6 & 25 & 38 \\
\hline U de Montréal & 699 & 44 & - & 3 & 一 & 85 \\
\hline U of Toronto & 550 & 55 & - & 15 & 110 & - \\
\hline U Laval & 405 & 20 & - & - & 6 & 45 \\
\hline UBC (British Columbia) & 383 & 29 & 1 & 一 & 6 & 53 \\
\hline WLU (Wilfrid Laurier) & 305 & 20 & - & 5 & 60 & 40 \\
\hline$U$ of Manitoba & 256 & 20 & - & 2 & 一 & 45 \\
\hline UNB (New Brunswick) & 250 & 一 & - & 1 & 3 & - \\
\hline U of Alberta & 220 & 20 & - & 5 & 39 & - \\
\hline U de Sherbrooke & 209 & 6 & - & 2 & - & 28 \\
\hline $\begin{array}{l}\text { Memorial U of } \\
\text { Newfoundland }\end{array}$ & 200 & 22 & - & 1 & 12 & - \\
\hline Queen's U & 200 & 11 & - & 5 & 27 & - \\
\hline Brandon U & 172 & 19 & - & 一 & 10 & - \\
\hline U of Calgary & 153 & 16 & 2 & 1 & 一 & 31 \\
\hline U of Lethbridge & 145 & 12 & - & 4 & 一 & 10 \\
\hline$U$ of Windsor & 113 & 9 & - & 一 & 一 & 25 \\
\hline Dalhousie U & 88 & 10 & - & 3 & 7 & 16 \\
\hline St. Fr. Xavior U & 85 & 7 & - & 2 & 2 & - \\
\hline$U$ of Regina & 75 & 9 & - & 2 & 4 & - \\
\hline Mount Allison U & 74 & 10 & - & 一 & 15 & - \\
\hline Canadian Mennonite $U$ & 70 & - & - & - & - & - \\
\hline $\mathrm{U}$ of $\mathrm{T}$ at Scarborough & 70 & 3 & - & 一 & 3 & - \\
\hline Carleton U & 62 & 10 & - & 一 & 9 & 15 \\
\hline Lakehead U & 60 & 3 & - & 一 & 18 & - \\
\hline Bishop's U & 50 & 3 & - & 一 & 4 & 15 \\
\hline Laurentian U & 44 & 3 & - & 一 & 25 & 18 \\
\hline U of Guelph & 40 & 一 & - & 一 & 一 & - \\
\hline U of Waterloo & 40 & 4 & - & - & 13 & 19 \\
\hline Brock U & 35 & 6 & 1 & 7 & 12 & - \\
\hline
\end{tabular}

aFull-time tenure-track

${ }^{\text {bPart-time tenure-track }}$

cFull-time non-tenure-track

dpart-time non-tenure-track 
APPENDiX D: RATIO OF STUDENTS TO FULL-TIME TENURE-TRACK (X:1)

\begin{tabular}{|c|c|c|c|}
\hline Institution & Total & FTTT & Ratio \\
\hline McGill & 818 & 57 & 14 \\
\hline UWO (Western Ontario) & 708 & 35 & 20 \\
\hline U de Montréal & 699 & 44 & 16 \\
\hline $\mathrm{U}$ of Toronto & 550 & 55 & 10 \\
\hline U Laval & 405 & 20 & 20 \\
\hline UBC (British Columbia) & 383 & 29 & 13 \\
\hline WLU (Wilfrid Laurier) & 305 & 20 & 15 \\
\hline U of Manitoba & 256 & 20 & 13 \\
\hline UNB (New Brunswick) & 250 & - & - \\
\hline$U$ of Alberta & 220 & 20 & 11 \\
\hline U de Sherbrooke & 209 & 6 & 35 \\
\hline Memorial U of Newfoundland & 200 & 22 & 9 \\
\hline Queen's U & 200 & 11 & 18 \\
\hline Brandon U & 172 & 19 & 9 \\
\hline $\mathrm{U}$ of Calgary & 153 & 16 & 10 \\
\hline$U$ of Lethbridge & 145 & 12 & 12 \\
\hline $\mathrm{U}$ of Windsor & 113 & 9 & 13 \\
\hline Dalhousie U & 88 & 10 & 9 \\
\hline St. Fr. Xavier U & 85 & 7 & 12 \\
\hline $\mathrm{U}$ of Regina & 76 & 9 & 8 \\
\hline Mount Allison U & 75 & 10 & 8 \\
\hline Canadian Mennonite $U$ & 70 & - & - \\
\hline $\mathrm{U}$ of $\mathrm{T}$ at Scarborough & 70 & 3 & 23 \\
\hline Carleton U & 62 & 10 & 6 \\
\hline Lakehead U & 60 & 3 & 20 \\
\hline Bishop's U & 50 & 3 & 17 \\
\hline Laurentian U & 44 & 3 & 15 \\
\hline$U$ of Guelph & 40 & - & - \\
\hline $\mathrm{U}$ of Waterloo & 40 & 4 & 10 \\
\hline Brock U & 35 & 6 & 6 \\
\hline
\end{tabular}




\section{APPENDIX E: UNDERGRADUATE PROGRAMS}

\begin{tabular}{|c|c|c|c|c|c|c|}
\hline Institution & General & B.A. & $\begin{array}{c}\text { B.Mus. } \\
\text { Ed. }\end{array}$ & Perf. & Comp. & Other \\
\hline McGill & 60 & - & 43 & 353 & 35 & Tech./SR \\
\hline $\begin{array}{l}\text { UWO (Western } \\
\text { Ontario) }\end{array}$ & 257 & 115 & 98 & 81 & 23 & $\begin{array}{l}\text { Mus. } \\
\text { Admin. }\end{array}$ \\
\hline U de Montréal & 113 & - & - & 222 & 50 & - \\
\hline $\mathrm{U}$ of Toronto & 50 & 10 & 85 & 248 & 11 & - \\
\hline U Laval & 30 & - & 162 & 108 & 8 & - \\
\hline $\begin{array}{l}\text { UBC (British } \\
\text { Columbia) }\end{array}$ & 72 & 71 & 42 & 141 & 10 & - \\
\hline WLU (Wilfrid Laurier) & 129 & - & 49 & 72 & 23 & Mus. TP \\
\hline$U$ of Manitoba & 107 & - & 53 & 62 & 4 & - \\
\hline UNB (New Brunswick) & 250 & - & - & - & - & - \\
\hline$U$ of Alberta & 46 & 38 & 59 & 26 & - & - \\
\hline U de Sherbrooke & 88 & - & 27 & 70 & - & Mul. Med. \\
\hline $\begin{array}{l}\text { Memorial } U \text { of } \\
\text { Newfoundland }\end{array}$ & 121 & 6 & 11 & 15 & - & - \\
\hline Brandon U & 8 & - & 34 & 30 & - & - \\
\hline$\cup$ of Calgary & 25 & 20 & 35 & 45 & 5 & - \\
\hline$U$ of Lethbridge & 145 & - & - & - & - & - \\
\hline$U$ of Windsor & - & 29 & 26 & - & - & Mus. TP \\
\hline Dalhousie U & 68 & 19 & - & 15 & 6 & - \\
\hline St. Fr. Xavier U & - & 15 & - & 27 & - & - \\
\hline$U$ of Regina & 2 & 14 & 23 & 29 & 3 & - \\
\hline Mount Allison U & 75 & 10 & - & - & - & - \\
\hline Carleton U & 102 & - & - & - & - & - \\
\hline Lakehead U & 39 & 14 & 5 & - & 2 & - \\
\hline Bishop's U & - & 50 & - & - & - & - \\
\hline Laurentian U & - & 44 & - & - & - & - \\
\hline$U$ of Guelph & - & 40 & - & - & - & - \\
\hline $\mathrm{U}$ of Waterloo & - & 40 & - & - & - & - \\
\hline Brock U & 35 & 35 & - & - & - & - \\
\hline Total & 1822 & 570 & 752 & 1544 & 180 & \\
\hline
\end{tabular}




\section{Appendix F: MAster's programs}

\begin{tabular}{|c|c|c|c|c|c|c|}
\hline Institution & Total & $\begin{array}{c}\text { Gradu- } \\
\text { ates }\end{array}$ & M.Mus. & $\begin{array}{l}\text { Perf. } \\
\text { Nos. }\end{array}$ & $\begin{array}{c}\text { Non-Perf. } \\
\text { Nos. }\end{array}$ & M.A. \\
\hline McGill & 818 & 255 & M.Mus./M.A. & 85 & 24 & 32 \\
\hline $\begin{array}{l}\text { UWO (Western } \\
\text { Ontario) }\end{array}$ & 708 & 120 & M.Mus./M.A. & 68 & 24 & 17 \\
\hline U de Montréal & 699 & 268 & M.Mus. & 98 & 22 & - \\
\hline U of Toronto & 562 & 148 & M.Mus./M.A. & 45 & 15 & 11 \\
\hline U Laval & 400 & 89 & M.Mus. & 36 & 40 & - \\
\hline $\begin{array}{l}\text { UBC (British } \\
\text { Columbia) }\end{array}$ & 383 & 109 & M.Mus./M.A. & 42 & 7 & 12 \\
\hline $\begin{array}{l}\text { WLU (Wilfrid } \\
\text { Laurier) }\end{array}$ & 305 & 12 & M.Mus. Therapy & - & 12 & - \\
\hline U of Manitoba & 256 & 15 & M.Mus. & 13 & 2 & - \\
\hline U of Alberta & 220 & 51 & M.Mus./M.A. & 20 & 12 & - \\
\hline U de Sherbrooke & 209 & 8 & M.Mus. & 8 & - & - \\
\hline $\begin{array}{l}\text { Memorial U of } \\
\text { Newfoundland }\end{array}$ & 200 & 35 & M.Mus./M.A. & 12 & - & 13 \\
\hline Brandon U & 172 & 12 & M.Mus. & 6 & 6 & - \\
\hline U of Calgary & 153 & 28 & M.Mus./M.A. & 13 & 4 & 4 \\
\hline U of Regina & 76 & 6 & M.Mus. & 3 & 1 & 2 \\
\hline Total & 5161 & 1156 & & 449 & 169 & 91 \\
\hline
\end{tabular}

\section{Appendix G: Doctoral Programs}

\begin{tabular}{|l|r|r|r|r|r|r||}
\hline \multicolumn{1}{|c|}{ Institution } & Total & Graduates & & & & \\
\hline McGill & 818 & 274 & D.Mus. & 24 & Ph.D.Mus. & 36 \\
\hline UWO (Western Ontario) & 708 & 120 & & & Ph.D.Mus. & 28 \\
\hline U de Montréal & 699 & 266 & D.Mus. & 63 & Ph.D.Mus. & 49 \\
\hline U of Toronto & 562 & 148 & D.Mus. & 16 & Ph.D.Mus. & 30 \\
\hline U Laval & 400 & 89 & & & Ph.D.Mus. & 13 \\
\hline UBC (British Columbia) & 383 & 109 & D.Mus. & 34 & Ph.D.Mus. & 14 \\
\hline U of Alberta & 220 & 51 & D.Mus. & 6 & Ph.D.Mus. & 13 \\
\hline Memorial U of Newfoundland & 200 & 35 & & & Ph.D.Mus. & 6 \\
\hline U of Calgary & 153 & 28 & & & Ph.D.Mus. & 7 \\
\hline Total & $\mathbf{4 1 4 3}$ & $\mathbf{1 1 2 0}$ & & 143 & & 196 \\
\hline
\end{tabular}




\section{Appendix H: Facilities and events}

\begin{tabular}{|c|c|}
\hline Institution & Facilities and events \\
\hline McGill & $3 \mathrm{CH} 600 / 186 / 300 ; 1 \mathrm{RH} 80 ; 700$ evts. \\
\hline UWO (Western Ontario) & $1 \mathrm{CH} 2300 ; 1 \mathrm{RH} 250 ; 1 \mathrm{TH} 400 ; 400$ evts. \\
\hline U de Montréal & $1 \mathrm{CH} 1000 ; 2 \mathrm{RH} \mathrm{100/100;} 550$ evts. \\
\hline U of Toronto & $1 \mathrm{CH} 900 ; 1 \mathrm{RH} 490 ; 500$ evts. \\
\hline U Laval & $1 \mathrm{CH} 270 ; 1 \mathrm{RH} 120 ; 1$ TH $660 ; 250$ evts. \\
\hline UBC (British Columbia) & $1 \mathrm{CH} 1400 ; 1 \mathrm{RH} 289 ; 1$ TH; 235 evts. \\
\hline WLU (Wilfrid Laurier) & $1 \mathrm{RH} 320 ; 1 \mathrm{TH} 500 ; 110$ evts. \\
\hline U of Manitoba & $1 \mathrm{RH} 224 ; 300$ evts. \\
\hline UNB (New Brunswick) & $1 \mathrm{CH} \mathrm{225;} 20$ evts. \\
\hline U of Alberta & $1 \mathrm{CH} 435 ; 1 \mathrm{RH} 60 ; 150$ evts. \\
\hline U de Sherbrooke & $1 \mathrm{RH} 80 ; 1 \mathrm{TH} 1726$ (Univ.); 100 evts. \\
\hline Memorial U of Newfoundland & 2 RH 296/124; 270 evts. \\
\hline Queen's U & 40 evts. \\
\hline Brandon U & $1 \mathrm{RH} 208 ; 120$ evts. \\
\hline U of Calgary & $2 \mathrm{RH} 384 / 200 ; 1 \mathrm{TH} 505$ \\
\hline U of Lethbridge & $1 \mathrm{CH} 375 ; 1 \mathrm{RH} 208 ; 1$ TH 205; 75 evts. \\
\hline U of Windsor & $1 \mathrm{CH} \mathrm{300;} 1 \mathrm{RH} \mathrm{66;} 57$ evts. \\
\hline Dalhousie U & $1 \mathrm{CH} \sim 1100$ (public $\mathrm{CH}$ ); $1 \mathrm{TH} 225 ; 90$ evts. \\
\hline St. Fr. Xavier U & $1 \mathrm{RH} 300 ; 20$ evts. \\
\hline U of Regina & $1 \mathrm{CH} 1500 ; 1 \mathrm{RH} 350 ; 1 \mathrm{TH} ; 50 ; 90$ evts. \\
\hline Mount Allison U & $1 \mathrm{CH} 600 ; 1 \mathrm{RH} 100 ; 1 \mathrm{TH} 410 ; \sim 35$ \\
\hline Canadian Mennonite U & 1 Aud. 250 \\
\hline $\mathrm{U}$ of $\mathrm{T}$ at Scarborough & $1 \mathrm{TH} 100 ; 4-6$ concerts \\
\hline Carleton U & $1 \mathrm{TH} 444 ; \sim 15-20$ evts. \\
\hline Lakehead U & $1 \mathrm{RH} 90 ; 20$ evts. \\
\hline Bishop's U & $1 \mathrm{RH} 160 ; 1 \mathrm{TH} 600 ; 35$ evts. in RH \\
\hline Laurentian U & $1 \mathrm{CH} 650$ (Univ.); 1 TH 157 (Univ.); 10 evts. \\
\hline U of Guelph & $1 \mathrm{CH} 825 ; 1$ LH 99; 20 evts. \\
\hline U of Waterloo & $1 \mathrm{RH} 120 ; 36$ evts. \\
\hline Brock U & 1 TH 550; 25 evts. \\
\hline
\end{tabular}

NotE: $\mathrm{CH}=$ concert hall; $\mathrm{RH}=$ rehearsal hall; $\mathrm{TH}=$ theatre 